\title{
Molecular cytogenetic analysis and clinical manifestations of a case with de novo mosaic ring chromosome 7
}

Li-Ping Tsai ${ }^{1,2+}$, Kuei-Fang Lee ${ }^{3+}$, Jye-Siung Fang ${ }^{3,4}$, Ingrid Y Liu ${ }^{4^{*}}$

\begin{abstract}
Aim: Clinical and molecular cytogenetic investigations of a newborn girl exhibiting facial dysmorphism with developmental delay.

Methods: Phenotypic evaluation was first applied to examine the proband's developmental status. Computed tomography and colour transcranial Doppler were used then to investigate her brain structure and function. Subsequently, chromosomal abnormalities were examined by karyotyping and fluorescent in situ hybridization was performed to investigate size of fragments lost at the two distal ends of the ring chromosome 7. In addition, multicolour banding was applied to rule out structural rearrangement occurs in between the ring chromosome 7.
\end{abstract}

Results: The proband was born with mosaic supernumerary ring chromosome 7, without a normal karyotype detected in the peripheral blood lymphocytes. The distal arm of chromosome $7 p$ (at least $255 \mathrm{~kb}$ from the telomere) was part of an extra ring chromosome 7. In addition, the distal arm of 7q, at least $8 \mathrm{~kb}$ from the telomere, was missing. There was no other chromosomal rearrangement detected by multicolour banding.

Interpretation: This is the $19^{\text {th }}$ reported case of complete ring chromosome 7 mosaicism and the first survived case with mosaic supernumerary ring 7 without a normal karyotype detected in the peripheral lymphocytes.

\section{Introduction}

Ring chromosome 7 is a rare chromosome anomaly that leads to variable phenotypes. The first two cases were described by Zackai et al in 1973 [1]. A total of 18 cases with complete ring chromosome 7 have been reported to date worldwide [1-17]. Ring chromosomes are often unstable during mitosis; therefore, it is common to find a ring chromosome in only a portion of all cells analyzed (mosaicism). The other cells in an individual, with a ring chromosome, are usually monosomic or demonstrate partial-trisomy with a small ring [18]. Here we present the $19^{\text {th }}$ case of complete ring chromosome 7 mosaicism. This is the first survived case with complete supernumerary ring 7 , without a normal karyotype detected in the peripheral lymphocytes. The phenotypic expression of patients with ring chromosome 7 is

\footnotetext{
* Correspondence: ycliu@mail.tcu.edu.tw

+ Contributed equally

${ }^{4}$ Department of Molecular Biology and Human Genetics, Tzu Chi University,

701, Sec 3, Chunyang Rd., Hualien 970, Taiwan

Full list of author information is available at the end of the article
}

variable; most patients demonstrate developmental delay, mental retardation, microcephaly, and dermatological abnormalities including cafe-au-lait spots, nevus flammeus and dark pigmented nevi (for review, please see [7]). The variable phenotypes may result from the variable size of the deleted chromosomes at the terminal segments, ring instability, and/or the level of mosaicism. The case presented here had microcephaly, hypotelorism, choanal stenosis, and speech delay, without any dermatological abnormalities detected to date.

\section{Methods}

\section{Patient and Clinical examination}

A female child with microcephaly (Figure $1 \mathrm{~A}$ and $1 \mathrm{~B}$, pictures taken at one year and 10 months of age) and respiratory distress was referred to the genetic counselling at the department of Pediatrics at Tzu Chi General Hospital in Taipei County, Taiwan. The proband was the first child of non-consanguineous parents. The Vietnamese mother was 23 at delivery, and the Taiwanese father was in his $40 \mathrm{~s}$. The proband was born by caesarean section with a birth
C Biomed Central

(c) 2011 Tsai et al; licensee BioMed Central Ltd. This is an Open Access article distributed under the terms of the Creative Commons Attribution License (http://creativecommons.org/licenses/by/2.0), which permits unrestricted use, distribution, and reproduction in any medium, provided the original work is properly cited. 


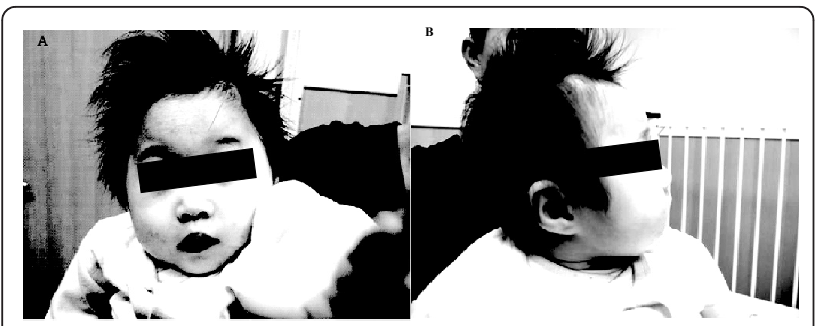

Figure 1 Pictures taken from the front $(A)$ and from the side (B) of the proband at her age of one year and 10 months old. Facial dysmorphism including hypotelorism, midface hypoplasia and high arch palate were noted. Choanal stenosis was suspected because of noise nasal breathing since birth. weight of $2410 \mathrm{gm}$, length $42 \mathrm{~cm}$ and head circumference of $30 \mathrm{~cm}$, all fall below the third percentile for gestational age. Facial dysmorphism was impressed, including hypotelorism, midface hypoplasia and high arch palate. Choanal stenosis was suspected because of noise nasal breathing since birth. Physical examination also detected subcutaneous syndactyly of $3^{\text {rd }}$ and $4^{\text {th }}$ toes. Computed tomography $(\mathrm{CT})$ and transcranial Doppler were directed due to microcephaly. CT of the brain showed mild stepage, widening of the upper part of the right lambdoid suture and mild scalp thickening along the course of the right lambdoid suture. The pediatric brain echo revealed normal ventricles and choroid plexus pulsation; however, a hypoechoic cyst-like lesion was noted next to the quadrigeminal plate. Speech delay and psychomotor retardation was noted during clinical evaluation at thirteen months old. The body weight of $5.4 \mathrm{Kg}$, height of $61 \mathrm{~cm}$ and head circumference of $35.2 \mathrm{~cm}$ still fell far below the third percentile on growth curve.

\section{Metaphases preparation and florescent in situ hybridization (FISH)}

Metaphases slides were prepared from lymphocyte cultures and G-banded for karyotyping using a standard protocol [19]. Five metaphase slides then were incubated in $2 \times \mathrm{SSC}(\mathrm{pH} 7.0)$ prewarmed to $37^{\circ} \mathrm{C}$ for $30 \mathrm{~min}$ for FISH analysis. After that, slides were dehydrated sequentially in a $70 \%, 85 \%$ and $100 \%$ ethanol series for $2 \mathrm{~min}$ each and then air dried. The metaphase slides were next denatured for $5 \mathrm{~min}$ in denaturant solution (70\% formamide $/ 2 \times \mathrm{SSC}$ ) in a $73^{\circ} \mathrm{C}$ water bath inside of a coplin jar, and then dehydrated in serial ethanol for $2 \mathrm{~min}$ each. Subsequently, $10 \mu \mathrm{l}$ of denatured probes (G31340 for chromosome 7q and G31341 for 7p, Cytocell, Ltd, Cambridge, UK) were added to the metaphase slides and then covered with a cover glass; the slides were placed in a prewarmed humidified box and incubated overnight at $42^{\circ} \mathrm{C}$ for hybridization. The next day, the cover glasses were removed immediately and the slides were washed with $0.4 \times \mathrm{SSC} / 0.3 \% \mathrm{NP} 40$ three times for
2 min each, and then air dried in the dark. Hybridization areas were counterstained with $20 \mu \mathrm{l}$ DAPI (Vysis Inc, IL, USA) and then examined under a fluorescence microscope.

\section{Multicolor banding}

Two metaphase slides were prepared for multicolour banding FISH analysis, Multicolor banding FISH probes for chromosome 7 (XCyte $724 \mu \mathrm{l}$ D-0207-024-MC, XCyte $724 \mu$ l D-0207-024-MC) were hybridized to metaphases using standard FISH protocol described above and viewed under the fluorescent microscope (Axioskop 40, Carl Zeiss Inc., Germany).

\section{Results}

Chromosome analysis of the peripheral lymphocytes revealed a mosaic karyotype. Out of 100 cells analyzed, a 46,XX,r(7)(p22q36) (Figure 2A) complement was observed in 75 cells (75\%); 45,XX, -7 (Figure 2B) in 12 cells (12\%); 47,XX,r(7)(P22q36), $+\mathrm{r}(7)(\mathrm{p} 22 \mathrm{q} 36)$ (Figure 2C) in five cells (5\%); 46,XX,dic r(7;7)(p22q36;p22q36) (Figure 2D) in four cells $(4 \%) ; 47, \mathrm{XX}, \mathrm{r}(7),+\operatorname{dicr}(7 ; 7)$ (p22q36;p22q36), and 47,XX,r(7),+inv(7)(p11.1-p22::p36q11.1) in two cells (2\%). A total of $13 \%$ of the examined cells revealed a supernumerary ring 7 . Skin fibroblast analysis was planned but the family did not return for further evaluations. A subtelomere specific probe was hybridized to metaphase cells by fluorescent in situ hybridization (FISH) to determine how much of the distal region of chromosome 7 remained intact in the ring chromosome 7. The results showed that the distal segment of chromosome $7 \mathrm{p}$ (at least $255 \mathrm{~kb}$ from telomere) appeared to be present in all of the ring chromosome

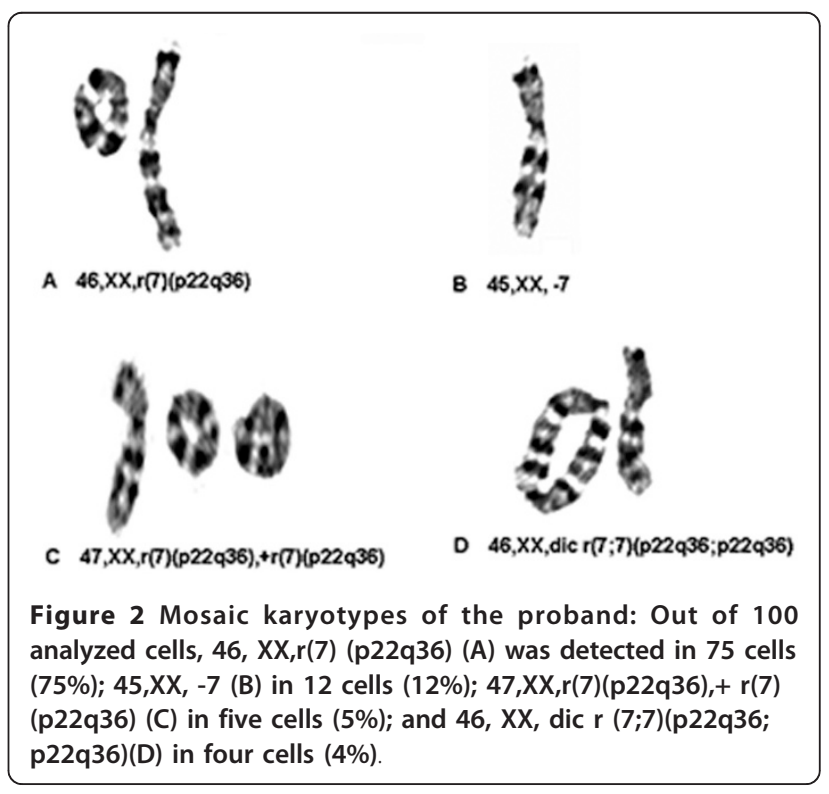


7 fragments (Figure 3A-C). However, the distal segment of chromosome $7 \mathrm{q}$ (at least $8 \mathrm{~kb}$ from telomere) was missing (Figure 3D).

Multicolour banding was performed to determine whether a micro-rearrangement occurred in the ring chromosome 7. Multicolor chromosome 7 banding probes that specifically detect various regions along chromosome 7 were hybridized to metaphases and viewed under the fluorescent microscope. No chromosome rearrangement was detected (Figure 4).

\section{Discussion}

A ring chromosome is formed by telomere-to-telomere fusion with minimal or no loss of genomic material. Ring chromosomes are often unstable during mitosis; as a result, it is common to find a ring chromosome in only a portion of cells (mosaicism). The other cells in the individual are usually monosomic or demonstrate partial-trisomy. Some cells lose the ring chromosome and some cells maintain a supernumerary ring chromosome in which the ring is usually small and composed
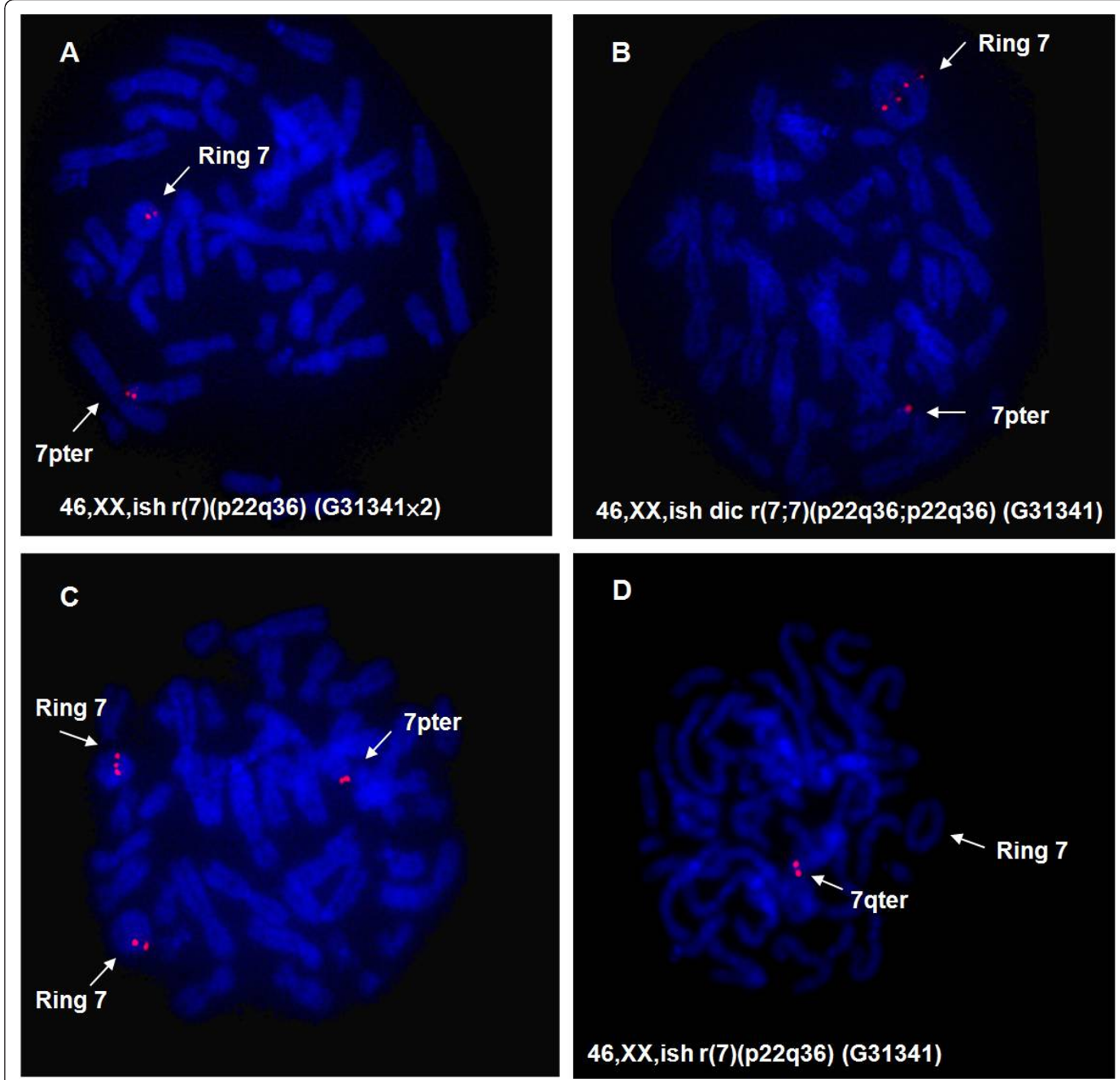

Figure 3 Flourescent In Situ Hybridization (FISH) using 7p and 7q sub-telomere probes: FISH with 7pter probe indicates subtelomeric region at least $\mathbf{2 5 5} \mathbf{~ k b}$ from telomere remained intact in all rings (A, B and C). However, the 7qter probe indicates that at least $8 \mathrm{~kb}$ from telomere was missing in the ring (D). 


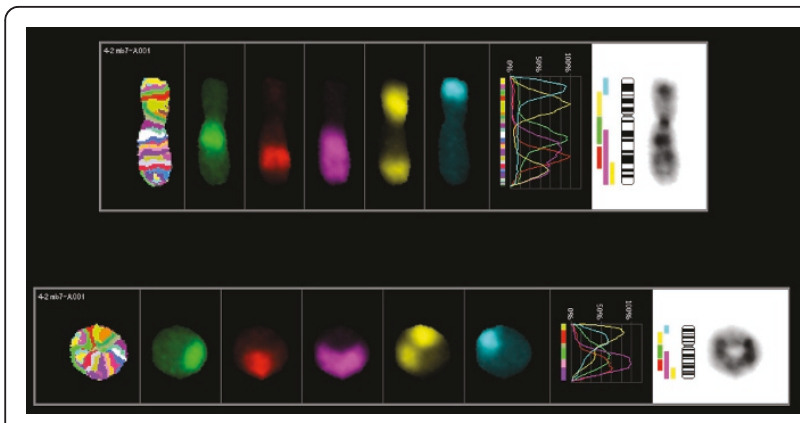

Figure 4 Multicolor banding of normal and ring chromosome 7: Multicolor banding probes that specifically detect various regions along chromosome 7 were hybridized to metaphases; no rearrangement was observed in normal ring 7 chromosomes.

mostly of the centromere and a small amount of euchromatic material [19].

The karyotype of the patient presented in this report was complicated and unique. There was no normal karyotype detected in the peripheral blood lymphocytes. Monosomy 7, one complete ring, supernumerary large rings, and duplicated rings of chromosome 7, were detected. Most previous reported cases of supernumerary ring chromosome 7 showed a majority of cells with a normal karyotype, in addition to some cells with a partial trisomy containing small rings [20-26]. Here we present a newborn girl that survived with a mosaic karyotype with a complete supernumerary ring chromosome 7 and a few monosomy 7 cells, without any cell with normal karyotype detected in peripheral lymphocytes. All large rings have an intact 7p G31341 region with the $7 \mathrm{q}$ telomere absent ( $8 \mathrm{~kb}$ from telomere). According to the human chromosome 7 view map (http://www.ncbi.nlm.nih.gov) of the National Centre for Biotechnology Information (NCBI), there are no functional genes located within the missing distal region of $7 q$. There might be a microdeletion at the $7 p$ telomere; however, no commercial probe available yet to detect a missing segment in this region.

In a previous report of two cases with complete trisomy ring 7 the infants were stillborn $[27,28]$. In the present case, a majority of cells (75\%) were composed of $46, \mathrm{XX}$, $r(7)$, and all of the large rings appeared to be stable; this is likely associated with the patient's survival. However, it is also possible that other tissues, beside the peripheral lymphocytes, had a normal karyotype; but no other tissue samples were available for analysis. The influence of gene dosage effects resulting from monosomy chromosome 7 (12\%) and supernumerary ring chromosome 7 (13\%) were likely the cause of the abnormal clinical characteristics in the patient reported here. We also assumed uniparental disomy (UPD) of chromosome 7 was associated with the proband's clinical manifestation, however, further examination for UPD was not possible due to relocation of this family.

The clinical expression of ring chromosome 7 is variable. Nevertheless, most cases share some characteristics such as: mental retardation, growth deficiency, mild microcephaly, facial asymmetry, hypertelorism, abnormal palpebral fissures, small ears, limb and skeletal anomalies, and skin lesions, including nevus flammeus, dark pigmented nevi and café-au-lait spots [7,10]. Our patient had some of these findings e.g. growth retardation, microcephally. However, no pigmented nevi or caféau-lait spots were observed at the time of evaluation. In addition, speech delay was noted. These findings suggest that some of the genes located within the affected region of chromosome 7 are associated with the cognitive abilities needed for speech development and might illustrate a dosage-dependent pattern.

In summary, we present the first case of survival with a mosaic and supernumerary complete ring chromosome 7, without a normal karyotype detected in peripheral blood lymphocytes. The high percentage (75\%) of cells with a stable $46, \mathrm{XX}, \mathrm{r}(7)$, the absence of a macrodeletion and rearrangement within the ring chromosome 7 are likely the major reasons accounting for the viability of this patient.

\section{Consent}

Written informed consent was obtained from the parents of the patient for publication of this case report and accompanying images.

\section{Acknowledgements}

This study was supported by Ministry of Economic Affairs, Taiwan, grant 98EC-17-A-19-S2-0110. We are grateful to Dr. Ming-Liang Lee for helpful comments on the manuscript.

\section{Author details}

'Department of Pediatrics, Buddhist Tzu Chi General Hospital, Taipei Branch, 289, Jianguo Rd., Sindian City, Taipei County 231, Taiwan. ${ }^{2}$ Department of Medicine, Tzu Chi University, 701, Sec 3, Chunyang Rd., Hualien 970, Taiwan. ${ }^{3}$ Laboratory for Cytogenetics, Centre for Genetic Counselling, Buddhist Tzu Chi Hospital, 701, Sec 3, Chunyang Rd., Hualien 970, Taiwan. ${ }^{4}$ Department of Molecular Biology and Human Genetics, Tzu Chi University, 701, Sec 3, Chunyang Rd., Hualien 970, Taiwan.

Authors' contributions

L-PT carried out pedigree analysis, clinical examination and diagnosis of this family, drafted "Patient and clinical examination" section. K-FL carried out cytogenetic and molecular cytogenetic experiments. J-SF carried out analysis of cytogenetic studies and interpretation of karyotype. IYL conceived of the study, and participated in its design, coordination and manuscript writing. All authors read and approved the final manuscript.

\section{Competing interests}

The authors declare that they have no competing interests.

Received: 14 September 2010 Accepted: 8 February 2011 Published: 8 February 2011 


\section{References}

1. Zackai EH, Breg WR: Ring chromosome 7 with variable phenotypic expression. Cytogenet Cell Genet 1973, 12(1):40-48.

2. Barros LP PA, Brunoni D, Andrade JAD: Cromosomo 7 emanel-relato de um caso. Cienc Cult 1986, 38:849.

3. Biesecker LG C, Glover TW: Severe anomalies associated with ring chromosome 7. American Journal of Medical Genetics 1991, 40:429-431.

4. Caramia GM, Baroncini A, Osimani P, Forabosco A: Ring chromosome 7: report of the fifth case. Eur J Pediatr 1990, 149(7):475-476.

5. Ceballos-Quintal JM, Pinto-Escalante D, Castillo-Zapata H, Canto-Herrera J: Severe congenital hypoacusia in a patient with mosaic ring chromosome 7. Rev Biomed 1999, 10:235-239.

6. DeLozier CD, Theintz G, Sizonenko $P$, Engel E: A fourth case of ring chromosome 7. Clin Genet 1982, 22(2):90-98.

7. Kaur A, Dhillon S, Garg PD, Singh JR: Ring chromosome 7 in an Indian woman. J Intellect Dev Disabil 2008, 33(1):87-94.

8. Kohyama J, Watanabe S, Nakajima M, Suzumura H, Ishikawa T, Ishikawa K, Saito F, Fukuda C: Ring chromosome 7: report of a case. Acta Paediatr Jpn 1988, 30:517-519.

9. Koiffmann CP, Diament A, de Souza DH, Wajntal A: Ring chromosome 7 in a man with multiple congenital anomalies and mental retardation. J Med Genet 1990, 27:462-464.

10. Mehraein Y, Ehlhardt S, Wagner A, Gottert E, Tilgen W, Zang KD, DillMuller D: Somatic mosaicism of chromosome 7 in a highly proliferating melanocytic congenital naevus in a ring chromosome 7 patient. Am J Med Genet A 2004, 131(2):179-185.

11. Nakano S, Miyamoto N: A ring C7 chromosome in a mentally and physically retarded male with various somatic abnormalities. Jinrui Idengaku Zasshi 1977, 22:33-41.

12. Rodriguez L, Sanchis A, Villa A, Canovas A, Peris S, Estivalis M, Pons S, Martinez-Frias ML: Ring chromosome 7 and sacral agenesis. Am J Med Genet 2000, 94(1):52-58.

13. Sawyer JR, Lukacs JL, Hassed SJ, Arnold GL, Mitchell HF, Muenke M: Subband deletion of 7q36.3 in a patient with ring chromosome 7: association with holoprosencephaly. Am J Med Genet 1996, 65:113-116.

14. Tsai PY LY, Chang CH, Chang FM, Kuo PL: Ring chromosome 7 presenting with intrauterine growth restriction and multiple anomalies. Taiwanese Journal Obstet Gynecol 2005, 44(3):297299.

15. Tsukamoto H, Sakai N, Taniike M, Nakatsukasa M, Yoshiwara W, Sakamoto H, Fujimura $\mathrm{H}$, Inui K, Okada S: Case of ring chromosome 7: the first report of neuropathological findings. Am J Med Genet 1993, 46(6):632-635.

16. Vermeesch JR, Baten E, Fryns JP, Devriendt K: Ring syndrome caused by ring chromosome 7 without loss of subtelomeric sequences. Clin Genet 2002, 62(5):415-417.

17. Wahlstrom J, Bjarnason R, Rosdahl I, Albertsson-Wikland K: Boy with a ring 7 chromosome: a case report with special reference to dermatological findings. Acta Paediatr 1996, 85(10):1256-1260.

18. Mueller RF, Young ID: Chromosomes and Cell Division. In Emery's Elements of Medical Genetics. Volume Chapter 3. 11 edition. Churchill Livingstone Elsevier; 2007

19. Barch MJ: The ACT Cytogenetics Laboratory Manual. Raven Press, New York: 21991.

20. Bertini V, Valetto A, Uccelli A, Bonuccelli A, Tarantino E, Taddeucci G, Simi P: Molecular cytogenetic characterization of a de novo mosaic supernumerary ring chromosome 7: report of a new patient. Am J Med Genet A 2008, 146A(22):2955-2959.

21. Chantot-Bastaraud S, Muti C, Pipiras E, Routon MC, Roubergue A, Burglen L, Siffroi JP, Simon-Bouy B: Clinical findings and cytogenetic analysis of small supernumerary ring chromosomes 7: report of two new cases. Ann Genet 2004, 47(3):241-249.

22. Combi R, Sala E, Villa N, Crosti F, Beccaria L, Cogliardi A: Tenchini ML, Dalpra L. Maternal heterodisomy/isodisomy and paternal supernumerary ring of chromosome 7 in a child with Silver-Russell syndrome. Clin Dysmorphol 2008, 17(1):35-39.

23. Lichtenbelt KD, Hochstenbach $R$, van Dam WM, Eleveld MJ, Poot M, Beemer FA: Supernumerary ring chromosome 7 mosaicism: case report, investigation of the gene content, and delineation of the phenotype. Am J Med Genet A 2005, 132A(1):93-100.

24. Tan-Sindhunata $G$, Castedo S, Leegte B, Mulder I, vd Veen AY, vd Hout AH, Wiersma TJ, van Essen AJ: Molecular cytogenetic characterization of a small, familial supernumerary ring chromosome 7 associated with mental retardation and an abnormal phenotype. Am J Med Genet 2000, 92(2):147-152

25. Velagaleti GV, Jalal SM, Kukolich MK, Lockhart LH, Tonk VS: De novo supernumerary ring chromosome 7 : first report of a non-mosaic patient and review of the literature. Clin Genet 2002, 61(3):202-206.

26. von Beust G, Sauter SM, Liehr T, Burfeind P, Bartels I, Starke H, von Eggeling F, Zoll B: Molecular cytogenetic characterization of a de novo supernumerary ring chromosome 7 resulting in partial trisomy, tetrasomy, and hexasomy in a child with dysmorphic signs, congenital heart defect, and developmental delay. Am J Med Genet A 2005, 137(1):59-64.

27. Verp MS, Amarose AP: Chromosomal mosaicism of trisomy 7 restricted to chorionic villi. Am J Med Genet 1987, 28(1):221.

28. Yunis E, Ramirez E, Uribe JG: Full trisomy 7 and Potter syndrome. Hum Genet 1980, 54(1):13-18.

doi:10.1186/1755-8166-4-5

Cite this article as: Tsai et al:: Molecular cytogenetic analysis and clinical manifestations of a case with de novo mosaic ring chromosome 7. Molecular Cytogenetics 2011 4:5.

\section{Submit your next manuscript to BioMed Central and take full advantage of:}

- Convenient online submission

- Thorough peer review

- No space constraints or color figure charges

- Immediate publication on acceptance

- Inclusion in PubMed, CAS, Scopus and Google Scholar

- Research which is freely available for redistribution
C Biomed Central 